\title{
Hydnellum gracilipes - a link between stipitate and resupinate Hymenomycetes
}

\author{
URMAS KÕLJALG and PERTTIRENVALL
}

\begin{abstract}
KÕLJALG, U. \& RENVALL, P. 2000: Hydnellum gracilipes - a link between stipitate and resupinate Hymenomycetes. - Karstenia 40: 71-77. Helsinki. ISSN 0435-3402.

Taxonomy and phylogeny of Hydnellum gracilipes (P. Karst.) P. Karst. (Thelephorales, Hymenomycetes) was revised. The species is characterized by soft and resupinate sporocarps, and the morphology supports a close relationship with tomentelloid fungi. The phylogenetic interpretation of the sequence data from the 5 ' end of nuclear large subunit (nucLSU) rDNA showed, however, that the closest relatives of $H$. gracilipes are found in the genus Hydnellum P. Karst. The evolution of the resupinate fruitbody is outlined. The ecology of the species is discussed and it is proposed that $H$. gracilipes is a mycorrhizal fungus. Six new localities are listed.
\end{abstract}

Key words: charred wood, forest fire, fruit body evolution, Hydnellum, molecular phylogeny, mycorrhiza, Thelephorales

Urmas Kõljalg, Institute of Botany and Ecology, University of Tartu, 40 Lai St, 51005 Tartu, Estonia and Institute of Zoology and Botany, 181 Riia St, EE 51014 Tartu, Estonia.E-mail: urmas@zbi.ee

Perti Renvall, Kuopio Natural History Museum, Myhkyrinkatu 22, FIN-70100 Kuopio, Finland.E-mail: pertti.renvall@kuopio.fi

\section{Introduction}

The original description of Hydnum gracilipes $\mathrm{P}$. Karst. (Hydnellum gracilipes (P.Karst.) P. Karst.) was validly published by Karsten (1866) in the Fungi Fenniae Exs. No. 521. Two years later he (Karsten 1868) provided a more detailed description of the species. There are three specimens of $H$. gracilipes collected by Karsten himself in the Botanical Museum of the University of Helsinki (H). They all derive from the same locality in Tammela, Mustiala, and were collected in August, 1866.

New material of Hydnellum gracilipes was collected in 1988-1996 from northern Finland by the second author (PR) of this paper, and in 1996 one collection became available from Norway. According to the earlier data (Maas Geesteranus 1975, Stalpers 1993, Strid 1997) this species is a pileate and distinctly stipitate fungus. However, the new collections presented here show that $H$. gracilipes exhibits some morphological characters which are not found in the other species of the genus Hydnellum. Specimens collected from Finland and Norway have resupinate fruit bodies and were chiefly growing on dead wood against the ground. Therefore they were at first treated as tomentelloid fungi, and Renvall (1995) reported the species as Pseudotomentella sp. 1.

This paper is dedicated to Dr. Tuomo Niemelä (University of Helsinki) on the occasion of his $60^{\text {th }}$ birthday. We here revise the systematics of Hydnellum gracilipes. We have utilized the 5' end of the nuclear large subunit (nucLSU) rDNA sequences to study the phylogeny of $H$. gracilipes. We also outline the possible evolution of the stipitate type of fruit body towards the resupinate type. 


\section{Material and methods}

For light microscope studies, samples were mounted in $3 \%$ potassium hydroxide $(\mathrm{KOH})$. In addition, Cotton Blue (CB) and Melzer's reagent (IKI) was used. For all measurements pictures of the samples were grabbed to the computer using Sony CCD Video Camera attached to the Nikon Labophot 2 microscope and analysed by Global Lab Image (Data Translation Inc.) software. The colour name is given according to Rayner (1970), and colour indices according to the Munsell (1976) colour system. For the methods of scanning electron microscopy (SEM) see Kõljalg (1996).

DNA was extracted from herbarium specimens with a modified 2\% CTAB method (Savolainen et al., 1995) and after isolation purified with GeneClean kit (Bio 101 Inc.). The PCR amplification was performed for 5' end of nucLSU rDNA, using primers LR0R and LR7. PCR conditions followed Gardes and Bruns (1993). The presence of fragments was checked on a $0.6 \%$ SeaKem agarose gel and amplified products were purified with the QIAquick kit (Qiagen Inc.) according to the manufacturer's instructions. The direct DNA sequencing was performed on an ALFexpress (Pharmacia Biotech) automated sequencher. Thermo Sequenase fluorescent labelled primer cycle sequencing kit (Amersham Int.) and primers LR3R, LR5, LR21, and CTB6 were used for cycle sequencing. The sequences were edited with Sequencher (GeneCodes Inc.) for the Macintosh OS and aligned by hand. The phylogenetic and distance analyses were performed for 27 species of Thelephorales using beta version $4.0 \mathrm{~b} 2 \mathrm{a}$ of PAUP* by David L. Swofford (Swofford, 1991). The calculations for the maximum parsimony analyses were conducted as follows: heuristic search, addition sequence random, number of replicates 1000, tree bisection-reconnection (TBR) swapping and

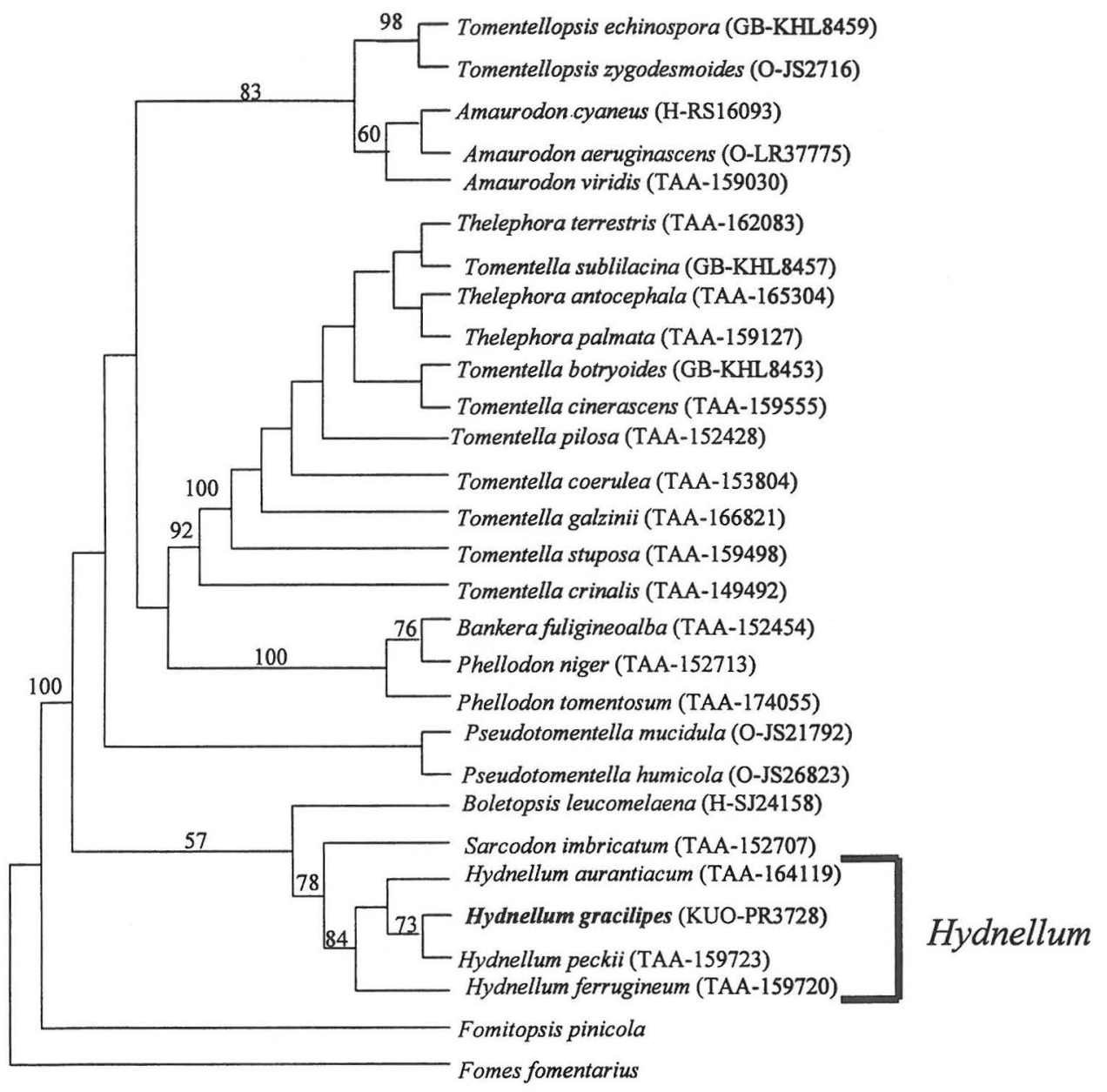

Fig. 1. The most parsimonious tree showing the placement of Hydnellum gracilipes (P. Karst.) P. Karst. among Thelephorales (Length $=660$ ). Bootstrap values $>50$ from 100 replications are indicated above the branch. 
MULPARS ON option, gaps were treated as "missing", 1499 characters were included from what 169 were parsimony-informative. Distance analyses included the neighbour joining with Jukes-Cantor and HKY85 substitution models.

The nomenclature of the Thelephorales follows Stalpers (1993), Kõljalg (1996) and Strid (1997). Coordinates of the Finnish localities are given according to the Finnish national uniform grid system $\left(27^{\circ} \mathrm{E}\right)$. Herbarium abbreviations are according to Holmgren et al. (1990). The herbarium numbers of the voucher specimens sequenced are shown in Fig. 1. Collections are kept in the herbaria TAA, GB, H, KUO and O. We release here the sequence of Hydnellum gracilipes. All the other sequences will be published elsewhere - papers on phylogenetic studies of Thelephorales are under preparation. The sequences of Fomitopsis pinicola (Sw.: Fr.) P. Karst. and Fomes fomentarius (L.: Fr.) Fr. were obtained from Ellen Larsson (University of Göteborg) and used as an outgroup.

\section{Results and discussion}

\section{Phylogenetic analyses}

Although the basidiocarp morphology supported a close relationship to tomentelloid fungi, in all parsimony and distance analyses Hydnellum gracilipes (the specimen $P R$ 3728) was nested together with $H$. aurantiacum (Batsch : Fr.) P. Karst., H. peckii Banker and H. ferrugineum (Fr. : Fr.) P. Karst. Therefore we are quite confident that $H$. gracilipes should be kept in the genus Hydnellum, where it was already placed by Karsten (1879). Heuristic search gave a single most parsimonious tree shown in Fig. 1.

\section{Taxonomy}

Hydnellum gracilipes (P. Karst.) P. Karst. - (Figs. 2-4)

Medd. Soc. Fauna Flora Fenn. 5: 41. 1879. - Hydnum gracilipes P. Karst., Fung. Fenn. Exsicc. 521. 1866; Notiser ur Sällskapets Pro Fauna et Flora Fennica förhandlingar 9: 362. 1868. - Lectotype: Finland. Etelä-Häme: Tammela, Mustiala, among mosses on the ground, 674: 32, 20.VIII.1866 P.A. Karsten 3406 (H!) selected here on the basis of the study of the original material by S. Huhtinen). - Calodon gracilipes (P. Karst.) P. Karst. in Re-

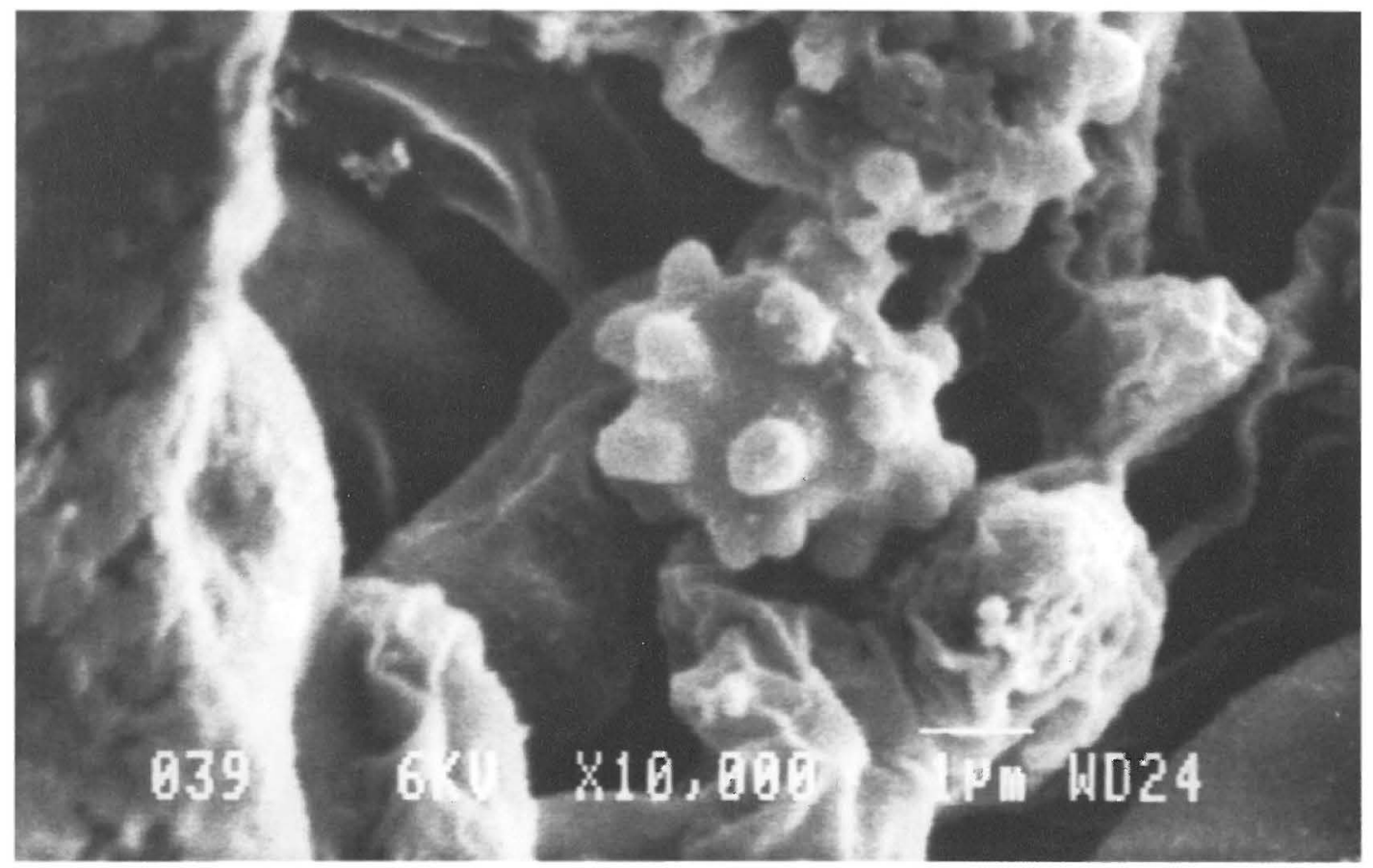

Fig. 2. Scanning electron micrograph of basidiospore of Hydnellum gracilipes (P. Karst.) P. Karst. (specimen $P$. Renvall 1062). 

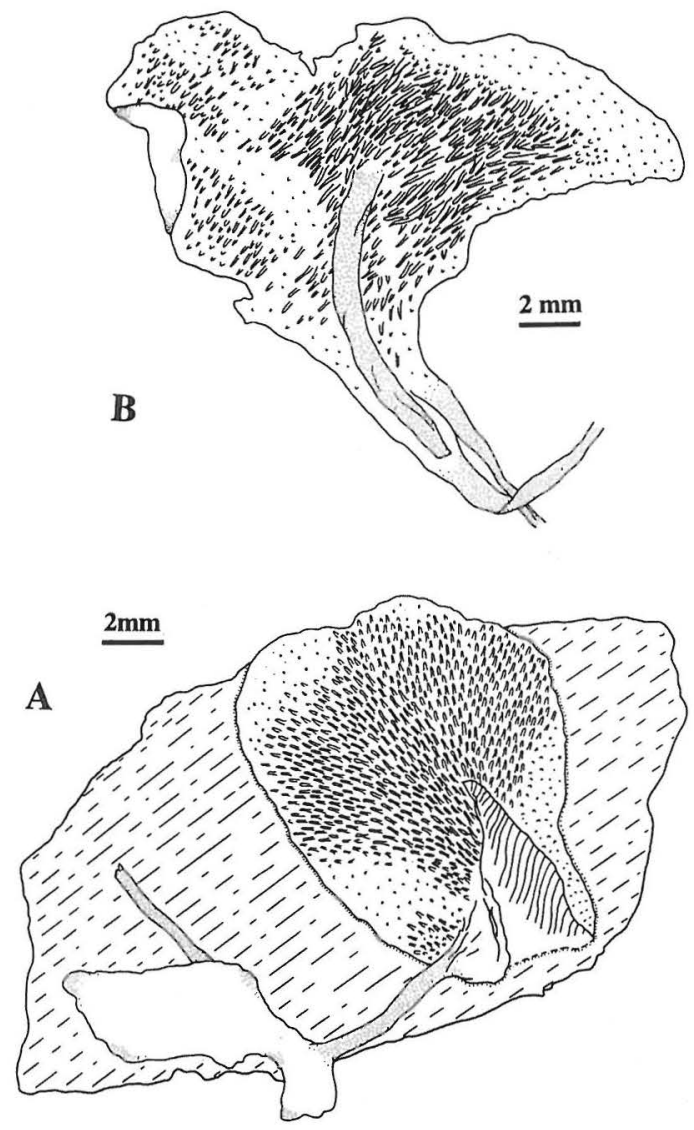

Fig. 3. Fruit bodies of Hydnellum gracilipes (P. Karst.) P. Karst. - A: specimen J.N. Stokland 26182. - B: specimen P. Renvall 3728.

vue Mycol. 3/No. 9: 20. 1881; Medd. Soc. Fauna Flora Fenn. 6: 16. 1881.

GeneBank® accession number: will be added AY012676.

Macromorphology: Basidiocarps annual, resupinate and loosely attached to substrate, with 1 (rarely 2 or 3) centric to lateral, $10-30 \mathrm{~mm}$ long and 2-5 mm diam., stipe-like rhizomorphs, very soft and fragile when fresh, brittle when dry. Hymenophore hydnoid, purplish brown when fresh, the red tint fade to more or less greyish brown during drying, near Fawn (7.5YR 5/4) when dry, concolorous with subiculum, spines more or less cylindrical, somewhat curved, tapering towards the sharp apex, $0.5-1.5$ (up to -21.5) (2) mm long, $5-(6) / \mathrm{cmm}$. Resupinate areas $1-5 \times 0.5-3 \mathrm{~cm}$ wide and up to 1.5 (2) mm thick.
Micromorphology: Hyphal system monomitic, all hyphae simple septate, dextrinoid andor cyanophilous, subicular hyphae hyaline to yellowish, 2-3.5 $\mu \mathrm{m}$ in diam., thin-walled, gloeoplerous hyphae present, some hyphae with brownish, granular encrustation, hyphal cords absent in subiculum but present in rhizomorphs. Tramal hyphae $2-4 \mu \mathrm{m}$ in diam, thin-walled, subparallel, some hyphae with brownish, granular encrustation, mostly hyaline to yellowish, in $3 \% \mathrm{KOH}$ some hyphae turn first lilac and then rapidly greenish, finally the colour mostly fades away, subhymenial hyphae 2-4 $\mu \mathrm{m}$ in diam, thin-walled, hyaline in $3 \% \mathrm{KOH}$. Cystidia absent. Basidia cyanophilous and dextrinoid, clavate, with 4 sterigmata, simple-septate at base, without transverse septa, hyaline in $3 \% \mathrm{KOH}, 20-24 \times 4.5-6.5 \mu \mathrm{m}$. Basidiospores subglobose in frontal face, ellipsoid in lateral face, tuberculate, yellowish brown in $3 \% \mathrm{KOH}$, cyanophilous $\mathrm{CB}+, 3.1-4.3 \mu \mathrm{m}$ long in frontal and lateral face (mean value $3.7 \mu \mathrm{m}, \mathrm{n}=$ 20/1), chlamydospores absent.

Specimens examined: Finland. Etelä-Häme: Tammela, Mustiala, among mosses on the ground, 674: 32, 20.VIII.1866 P.A. Karsten 3406 (H, lectotype), VIII.1866 P.A. Karsten 3405 (H, isolectotype), VIII.1866 P.A. Karsten 3407 (H). Koillismaa. Salla, Värriö Res. Sta., on charred wood of Pinus sylvestris and on debris, 7520: 610, 10.VIII.1988 P. Renvall $1062(\mathrm{H})$; Kittilän Lappi: Muonio, Äkäskero SW slope, on charred wood of Pinus sylvestris and on debris, 751: 37, 22.VIII.1999 T. Niemelä 6507 \& Dai (H). Sompion Lappi: Savukoski, Jaurujoki, Vongoivanmänniköt, on charred wood of Pinus sylvestris and on debris, 7560: 566, 27.VIII.1993 P. Renvall 3312 (KUO); Inarin Lappi: Inari, Laanila, on charred wood of Pinus sylvestris and on debris, 7586: 512, 13.VIII.1996 P. Renvall 3654 (KUO); Inari, Nukkumajoki, Lake Kivenjärvi, on charred wood of Pinus sylvestris and on debris, 7642: 498, 17.VIII.1996 P. Renvall 3728 (KUO).

Norway. Østfold, Römskog, Steinsvika, on Populus log, 20.X.1997 J.N. Stokland 26182 (O).

\section{Distribution and ecology}

The original description of Hydnellum gracilipes was based on the material collected by Karsten in 1866 from Tammela, Mustiala, southwestern Finland. Karsten $(1868,1881,1882)$ himself did not report further collections and described the species as very rare. Due to the rarity $H$. gracilipes remained enigmatic for a long time. The species was not mentioned by Nikolajeva (1961) but Maas Geesteraanus (1975) provided a description of the species on the basis of the type material and a collection from Sweden (Sö- 
dermanland: Nacka, between mosses, under a fallen pine trunk, G. Haglund \& R Rydberg 5. VIII.1948; UPS, not studied). Strid (1997) reported the species from Denmark (Western Jylland), Finland (Uusimaa and Etelä-Häme) and Sweden (Småland). We here list five new finds from Finland and the first collection from Norway. Although $H$. gracilipes seems to be very rare, it will probably be collected increasingly during forthcoming years. The species should be sought especially in old-growth pine forests with charred wood in northern Fennoscandia and Russia.

According to the ten known localities Hydnellum gracilipes is a rare fungus with a more or less northern distribution pattern. Most of the collections derive from dry forests predominated by Pinus sylvestris. The Norwegian specimen, however, was found on a Populus log in a mature southern boreal forest of deciduous trees. The Finnish sites were dry old-growth forests characterized by pine snags of different sizes, a number of fallen pine trunks at different stages of decom- position and the presence of charred wood. The field layer was low-growing and scanty, being formed by the dwarf shrubs Calluna vulgaris, Empetrum nigrum s. lat., Vaccinium vitis-idaea, $V$. myrtillus, and $V$. uliginosum. Lichens, especially Cladina spp., predominate in the ground layer, intermixed with the mosses Dicranum fuscescens, D. scoparium, Pleurozium schreberi and Polytrichum juniperinum.

The habitat ecology of Hydnellum gracilipes exhibits some special features. The fungus was found five times on old, uprooted and strongly charred pine trunks. The basidiocarps could be detected only if the trunks were lifted or turned. They were found on the undersides of the trunks that were closely attached to the ground but always partly also on debris below the trunks. These trees had fallen long ago and had evidently died, become decorticated and dried while standing. After the fall-down they had experienced one or several forest fires. Evidently the two top thirds of the trees had burned or com-

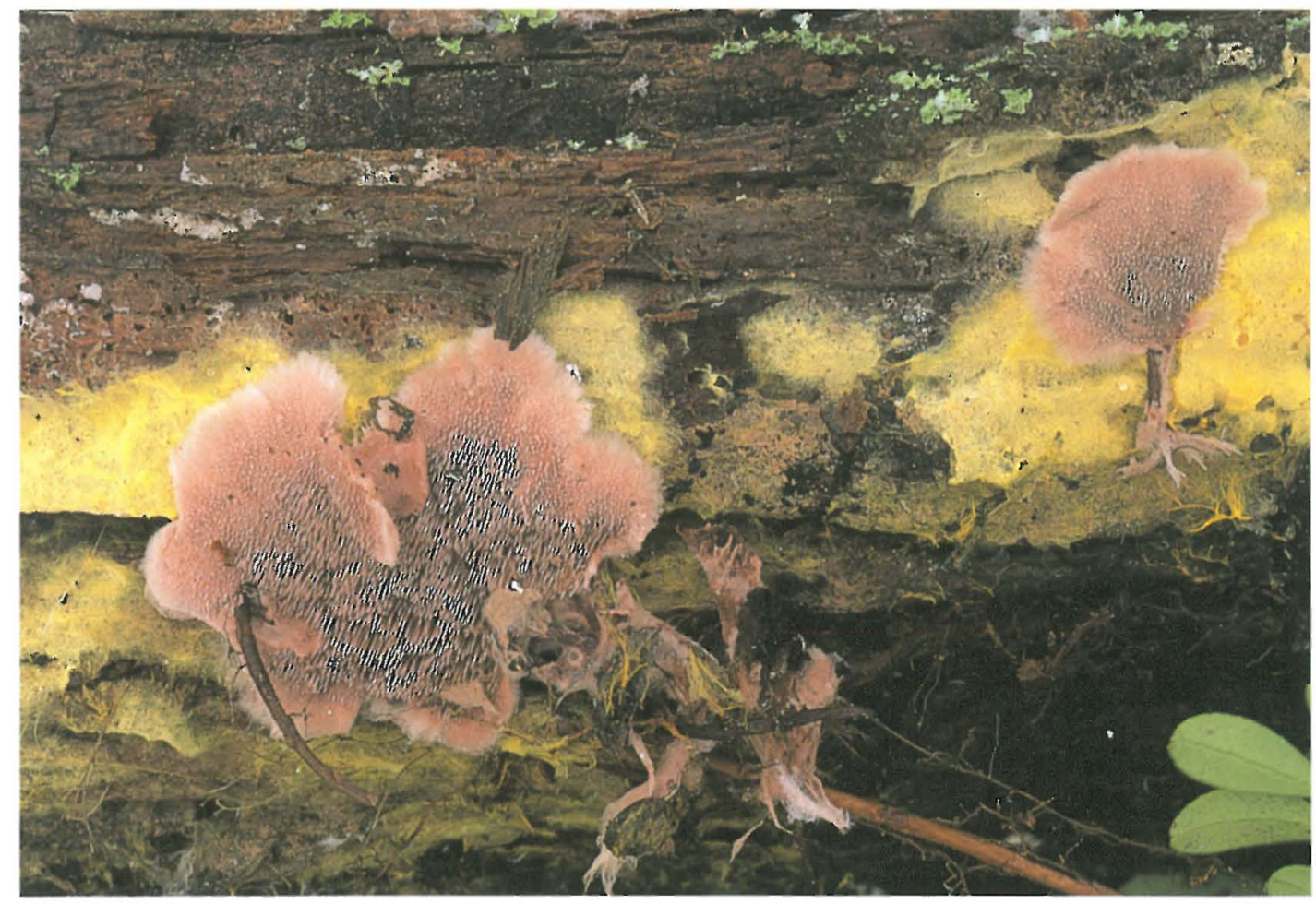

Fig. 4. Fruit body of Hydnellum gracilipes (P. Karst.) P. Karst. (specimen T. Niemelä $6507 \&$ Dai). Photographed in situ by T. Niemelä. 
pletely decomposed a long time ago but the hard, resin-rich and more voluminous basal parts, though heavily damaged by fire, had survived, at least partly, almost untouched. Therefore these remnants of trunks remind up-rooted natural stumps more than windblown trunks.

The species of Hydnellum are mycorrhizal fungi (Agerer 1991, 1993), and it is well supported that most resupinate tomentelloid fungi, closely related to stipitate Thelephorales, are mycorrhiza formers (Kõljalg et al. 2000, Kõljalg et al. submitted manuscript). Although found on charred wood it is therefore evident that also Hydnellum gracilipes has a life strategy of an terrestial mycorrhizal species. On the other hand the fungus may also contribute in decomposing the remnants of woody debris, particularly charred wood.

\section{Generic placement of Hydnellum gracilipes}

According to our view Hydnellum gracilipes does not have a real stipe which would bear a pileus. Instead, the fungus utilizes dead wood to support the basidiocarp. If traditional morphological criteria are used alone, it is therefore difficult to accept $H$. gracilipes in the genus Hydnellum. The soft and very fragile resupinate sporocarps, and the lack of real stipe are characters which do not fit at all in the genus of compact and tough stipitate fungi. It would be much more logical to try to find the closest relatives in the genera Pseudotomentella Svrcek or Tomentella Pat. However, the microscopical characters are more or less the same as in the other species of Hydnellum, and as shown in this study, the molecular data (Fig. 1) clearly support the inclusion of $H$. gracilipes in Hydnellum. The basidiocarp morphology also raises questions about the phylogeny of $H$. gracilipes and related taxa. According to the morphological characters the species seems to fall inbetween the true stipitate hydnums and resupinate tomentelloid fungi. However, instead of lumping genera together, the phylogenetic interpretation clearly divided the taxa into different clades according to the existing genera and supported the generic limits as proposed by morphology.

\section{Basidiocarp evolution}

Corner (1954) suggested that all "higher Basidiomycetes" with resupinate fruit bodies have evolved from stipitate forms. He put on two hypotheses for the possible evolution of resupinate fruitbodies, viz. "Ex hypothesi, they [resupinate fruit bodies, authors comm.] are derived from bracket and pileate forms from which all the form-factors of the fruit-body have most economically disappeared, except for the positively geotropic, rain-protected hymenium. Ex hypothesi, the resupinate Thelephoraceae [s.l., incl. all corticioid fungi, authors comm.] are a mixture of all lines of Basidiomycetes that have reached this state of efficiency.". Corner's (1954) hypotheses were accepted, e.g., by Jülich (1981) but later mostly critizised (see Parmasto 1986). We will not debate here which fruit body form might be the most ancient in the phylogeny of Homobasidiomycetes and how all the other types have evolved from it. For a rewiev on the phylogeny of corticioid fungi and the evolution of the fruit body types see Parmasto (1986) and Ryvarden (1991). Instead we comment on the hypothesis according to which the resupinate type of fruit body is a simplification of more complex pileate forms.

The mycorrhizal life strategy is generally considered as an advanced character among Basidiomycetes. Recent below-ground fungal community studies of ectomycorrhizal fungi (Gardes \& Bruns 1996, Erland \& Taylor 1999) have shown that in a variety of forest types the most important mycorrhizal fungi belong to corticioid and tomentelloid species with resupinate fruit bodies. Accordingly it is logical to assume that the resupinate fruit body type represents an advanced way to produce basidiospores. In addition, the frequence and world wide distribution of resupinate Thelephorales (tomentelloid fungi) seem to be much higher compared to the stipitate fungi of the same order (e.g. Stalpers 1993).

Many morphological papers have indicated that the classical form taxon Corticiaceae s. lat. (corticioid fungi) is a paraphyletic group. As clearly shown by a recent molecular study (Larsson et al. 1999) corticioid fungi are represented in a number phylogenetically homogeneous clades of Homobasidiomycetes, and in these clades fungi with pileate fruit body types are present as well. This supports Corner's (1954) idea that corticioid fungi represent a mixture of all phylogeny lines of Hymenomycetes. However, it does not prove his hypothesis that the resupinate fruit body type has evolved from the stipitate types. 
Hydnellum gracilipes provides a unique view to the evolution of different fruit body types. The stipe-like rhizomorphs may represent a degenerated stipe, while the resupinate part may have evolved from the pileus. On the other hand the stipe-like organs of $H$. gracilipes may represent an ancient character that belonged to fungi from which both resupinate and stipitate forms have evolved. At the moment we are not able to present detailed answers to these questions. $H$. gracilipes is, however, a peculiar fungus and by displaying the possible origin of the resupinate fruitbody type it may have a special role in forthcoming studies on the phylogeny of Hymenomycetes.

Acknowledgements: This study was financially supported by the Estonian Science Foundation grant no 4083 and additional funding was provided by the Carl Stenholm Foundation. We thank Ellen Larsson for providing the sequences of Fomes fomentarius and Fomitopsis pinicola and Jogeir N. Stockland for the Norwegian material. Seppo Huhtinen kindly gave advice on the typification of Hydnellum gracilipes. We also thank the curators of the herbaria $\mathrm{GB}, \mathrm{H}, \mathrm{KUO}, \mathrm{O}$ and TAA for arranging the loans of $H$. gracilipes specimens. We are indebted to Erast Parmasto and Karl-Henrik Larsson for discussions on the phylogeny of the fungi involved, and to Tuomo Niemelä for providing the colour slide.

\section{References}

Agerer, R. 1991: Ectomycorrhizae of Sarcodon imbricatus on Norway spruce and their chlamydospores. Mycorrhiza 1: 21-30.

Agerer, R. 1993: Ectomycorrhizae of Hydnellum peckii on Norway spruce and their chlamydospores. - Mycologia 85: 74-83.

Corner, J.H. 1954: The classification of the higher fungi. - Proceedings of the Linnean Society of London 165: 4-6.

Erland, S. \& Taylor, A.F.S. 1999: Resupinate ectomycorrhizal fungal genera. - In: Ectomycorrhizal fungi: key genera in profile. (eds. Cairney JWG, Chambers SM), pp 347-363. Springer Verlag, Heidelberg.

Gardes, M. \& Bruns, T.D. 1993: ITS primers with enhanced specificity for basidiomycetes - application to the identification of mycorrhizae and rusts. - Molecular Ecology 2: 113-118.

Gardes, M. \& Bruns, T.D. 1996: Community structure of ectomycorrizal fungi in a Pinus muricata forest: above- and below-ground views. - Canadian Journal of Botany 74:1572 572-1583.

Holmgren, P.K., Holmgren, N.H. \& Barnett, L.C. 1990: Index herbariorum 1. The herbaria of the world. 8th ed. - Regnum Vegetabile 120: 1-693.

Jülich, W. 1981: Higher taxa of Basidiomycetes. - Bibliotheca Mycologica 85, 485 pp., Cramer, Vaduz.
Karsten, P. A. 1866: Hydnum gracilipes. - Fungi Fenniae Exs. 521.

Karsten, P. A. 1868: Polyporei et Hydnacei, in paroecia Tammela crescentes. - Notiser ur Sällskapets pPro Fauna et Flora Fennica Fförhandlingar 9: 357-364.

Karsten, P. A. 1879: Symbolae ad Mycologiam fennicam 6. - Medd. Soc. Fauna Flora Fenn. 5: 15-46.

Kõljalg, U. 1996: Tomentella (Basidiomycota) and related genera in Temperate Eurasia. Synopsis Fungorum 9: 1-213.

Kõljalg, U., Dahlberg, A. F. S., Taylor, A., Larsson, E., Hallenberg, N., Stenlid, J., Larsson, K.-H., Fransson, P. M., Kåren, O. \& Jonsson L. 2000: Diversity and abundance of resupinate thelephoroid fungi as ectomycorrhizal symbionts in Swedish boreal forests. Molecular Ecology 9 (in press).

Kõljalg, U., Jakucs, E., Bóka, K. \& Agerer. R. Three ectomycorrhizae with cystidia formed by different Tomentella species as revealed by rDNA ITS sequences and anatomical characteristics. - Mycological Research (submitted).

Larsson, K.-H., Larsson, E. \& Kõljalg, U. 1999: Evolution of corticioid aphyllophoralean fungi. - Abstracts of the conference "25 Years of Mycology in Tübingen": . pp. 14-15. University of Tübingen, Tübingen.

Maas Geesteraanus, R.A. 1975: Die terrestrischen stachelpilze Europas. - 127 pp. North-Holland Publishing Comp., Amsterdam. $127 \mathrm{pp}$.

Munsell, A.H. 1976: Munsell book of color. - Baltimore: Munsell Color, Macbeth Division of Kollmorgen Corporation.

Nikolajeva, T.L. 1961: Flora Plantarum Cryptogamarum URSS Vol 6. Fungi 2. Familia Hydnaceae. 433 pp. Academia Nauk URSS, Moskva. 433 pp.

Parmasto, E. 1986: On the origin of the Hymenomycetes (What are corticioid fungi?). - Windahlia 16: $3-19$.

Rayner, R.W. 1970: A mycological colour chart. - Kew: Commonwealth Mycological Institute and British Mycological Society.

Renvall, P. 1995: Community structure and dynamics of wood-rotting Basidiomycetes on decomposing conifer trunks in northern Finland. - Karstenia 35: 1-51.

Ryvarden, L. 1991: Genera of polypores. Nomenclature and taxonomy. - Synopsis Fungorum 5: 1-363.

Savolainen, V., Cuénoud, P., Spichiger, R., Martinez, M.D.P., Michéle Crèvecoeur, M. \& Manen, J.F. 1995: The use of herbarium specimens in DNA phylogenetics: evaluation and improvement. - Plant Systematics and Evolution 197: 87-98.

Stalpers, J.A. 1993: The Aphyllophoraceous fungi I. Keys to the species of the Thelephorales. - Studies in Mycology 35: 1-168.

Strid, A. 1997: Bankeraceae Donk In: Hansen, L. \& Knudsen, H. (eds.), Nordic macromycetes 3. Heterobasidiod, aphyllophoroid and gastromycetoid basidiomycetes:. pp. 308-315. - Nordsvamp, Copenhagen.

Swofford, D. L. 1999: PAUP* 4.0 Phylogenetic Analysis Using Parsimony. Beta Version 4.0b2. Sinauer Ass., Sunderland. 